\title{
Reproductive aspects of freshwater fishes exposed to pesticide-contamined environments: A systematic review
}

\section{Jadson Pinheiro Santos ${ }^{1,4}$, Simone de Jesus Melo Almeida ${ }^{2}$, Claryce Cunha Costa ${ }^{2}$, Erick Cristofore Guimarães ${ }^{3}$, Erivânia Gomes Teixeira ${ }^{4}$ e Raimunda Nonata Fortes Carvalho-Neta ${ }^{5}$}

\begin{abstract}
${ }^{1}$ Universidade Federal do Maranhão. Programa de Pós-Graduação em Biodiversidade e Biotecnologia da Amazônia Legal - PPGBIONORTE. Cidade Universitária Dom Delgado. Av. dos Portugueses, 1.966. Vila Bacanga. São Luís-MA, Brasil (CEP 65080-805).

${ }^{2}$ Universidade Estadual do Maranhão. Programa de Pós-Graduação em Ciências Biológicas. Cidade Universitária Paulo VI. Av. Lourenço Vieira da Silva, 1.000. Jardim São Cristovão. São Luís-MA, Brasill (CEP 65055-310).

${ }^{3}$ Universidade Federal do Oeste do Pará. Instituto de Ciências da Educação. Programa de Pós-Graduação Sociedade Natureza e Desenvolvimento. Campus Universitário. Av. Mendonça Furtado, 2.946. Bairro Fátima. Santarém-PA, Brasil (CEP 68040-470). Email: erick.ictio@yahoo.com.br.

${ }^{4}$ Universidade Estadual do Maranhão. Departamento de Engenharia de Pesca. Cidade Universitária Paulo VI. Av. Lourenço Vieira da Silva, 1.000. Jardim São Cristovão. São Luís-MA, Brasil (CEP 65055-310).

5Universidade Estadual do Maranhão Departamento de Ciências Biológicas. Programa de Pós-Graduação em Biodiversidade e Biotecnologia da Amazônia Legal - PPGBIONORTE. Cidade Universitária Paulo VI. Av. Lourenço Vieira da Silva, 1.000. Jardim São Cristovão. São Luís-MA, Brasil (CEP 65055-310).
\end{abstract}

\begin{abstract}
Fish are the predominant group of vertebrates in aquatic environments, and they are directly affected by the presence of contaminants in water bodies, which undergo changes in the structure and function of communities and dynamics of the populations. The aim of the present study was to conduct a systematic review of studies that analyze the reproductive aspects of freshwater teleosts in environments contaminated by pesticides. A systematic search for scientific articles was carried out from 2000 to 2019 using the "Web of Science" database, using the descriptors "fish reproduction", "contamination", "toxicology", "ecotoxicity" and "biomonitoring", combined with the use of boolean operators "AND" and "OR". The content analysis was performed based on the titles and the summary, with a first screening. Then, 98 articles were read in full, with 40 being selected. 24 species of fish were recorded, with a predominance of Danio rerio (17.5\%). Insecticides were present in $78 \%$ of the studies, mainly Endosulfan (35\%) and

Received

May 19, 2021

Accept

August 27, 2021

Released

August 31, 2021

Open Access
\end{abstract}

ISSN 2359-1412/RBGAS-2021-0052/2021/8/19/35/1155 
Cypermethrin (13\%). Reproductive endocrine disorders were the most reported pathways of action (57.5\%). The effects of pesticides on the reproduction of freshwater teleosts are evident, requiring studies on structural changes in gonads and a decrease in the quality of gametes.

Keywords: Biomonitoring; Contamination; Ecotoxicity; Toxicology.

Resumo. Aspectos reprodutivos de peixes de água doce expostos a ambientes contaminados por pesticidas: uma revisão sistemática. Os peixes são o grupo de vertebrados predominante nos ambientes aquáticos, sendo diretamente afetados pela presença de contaminantes nos corpos d'água, que sofrem alterações na estrutura e função das comunidades e na dinâmica das populações. 0 objetivo do presente estudo foi realizar uma revisão sistemática de estudos que analisam os aspectos reprodutivos de teleósteos de água doce em ambientes contaminados por agrotóxicos. Foi realizada uma busca sistemática de artigos científicos publicados entre 2000 e 2019 na base de dados "Web of Science", utilizando os descritores "fish reproduction", "contamination", "toxicology", "ecotoxicity" and "biomonitoring", combinado com o uso dos operadores booleanos "AND" e "OR". A análise de conteúdo foi realizada com base nos títulos e na síntese, com uma primeira triagem. Em seguida, foram lidos 98 artigos na íntegra, sendo 40 selecionados. Foram registradas 24 espécies de peixes, com predomínio de Danio rerio $(17,5 \%)$. Os inseticidas estiveram presentes em $78 \%$ dos estudos, principalmente Endosulfan (35\%) e Cipermetrina (13\%). Os distúrbios endócrinos reprodutivos foram as vias de ação mais relatadas $(57,5 \%)$. Os efeitos dos agrotóxicos na reprodução dos teleósteos de água doce são evidentes, exigindo estudos sobre mudanças estruturais nas gônadas e diminuição na qualidade dos gametas.

Palavras-chave: Biomonitoramento; Contaminação; Ecotoxicidade; Toxicologia.

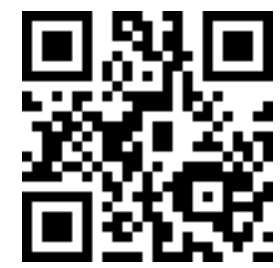

\section{ORCID}

(D) 0000-0002-7521-8835

Jadson Pinheiro

Santos

D) $0000-0002-9817-1638$

Simone de Jesus Melo Almeida

(1) 0000-0002-4626-7726 Claryce Cunha Costa

(1) 0000-0003-4480-5452

Erick Cristofore

Guimarães

D) 0000-0003-2931-2537

Erivânia Gomes

Teixeira

(D) 0000-0002-3519-5237

Raimunda Nonata

Fortes Carvalho-Neta

\section{Introduction}

The historical development of cities and agricultural growth have accelerated the degradation of natural environments through an increase in the disposal of various contaminants in aquatic environments (Begum, 2004; Marques and Américo-Pinheiro, 2020). This situation mainly affects freshwater bodies, leading to reduced availability of good-quality water for human supply, in addition to changes in physicochemical characteristics that support the maintenance of the natural biodiversity of aquatic fauna and flora (Massaro, 2006; Montanha et al., 2012; Paschoalini et al., 2019).

The toxicity of industrial and residual chemical compounds originating from agriculture has deleterious effects on both humans and other animals in the environment where they are found, especially fish in aquatic environments (Ribeiro and AméricoPinheiro, 2018). Often, these effects are not noticed because they do not cause the 
immediate death of aquatic organisms exposed to contaminants. However, sublethal concentrations can affect several morphological, physiological, and metabolic processes of fish when those contaminants penetrate their organs (Lins et al., 2010).

Fish are the predominant group of vertebrates in aquatic environments, and because they are a food resource frequently used worldwide, they are directly affected by the presence of contaminants in water bodies (Paschoalini et al., 2019). It is estimated that there are currently approximately 35,000 fish species, corresponding to more than $50 \%$ of vertebrate species (Fricke et al., 2021). Worldwide, fish have great environmental importance for aquatic ecosystems as well as social importance because they are an excellent source of animal protein for riverine populations that depend on the collection of these organisms for food and income generation (FAO, 2020).

Because they occupy different positions in the food chain of aquatic ecosystems, fish are often used as bioindicators of the environmental quality of ecosystems and are indicated as sentinel organisms that respond to changes at various structural levels, including cellular, physiological, biochemical, genetic, and histological, and to variations in behavior patterns, which can affect the population structure of the species in response to stressors in the environment (Lima et al., 2018). With the need to monitor the possible effects of toxic contaminants on aquatic biota, several studies on ecotoxicology have been conducted to evaluate the effect of toxic chemicals at different levels of organization, including cellular structures, individuals, populations, and communities (Costa et al., 2008; Pinto et al., 2020).

The deleterious effects caused by the action of contaminants in organisms propagate through other ecosystem components, causing changes in the structure and function of communities, such as changes in the predator-prey relationship, in ecosystem function or in the characteristics and dynamics of populations, especially migration, stock renewal and reproduction (Jones and Reynolds, 1997). Several Neotropical species have external fertilization as a reproductive strategy, which exposes the gametes to the contaminated environment (Rodrigues et al., 2019). Thus, the entire process of fertilization and embryonic development can be directly affected by excess contaminants, greatly influencing the reproduction and renewal of fish stocks, causing an environmental imbalance and reduction in species diversity (Mondal et al., 2015).

However, there are few studies that analyze the reproductive processes of freshwater fish in contaminated environments in an integrated manner, especially with regard to the toxic effects of pesticide residues in water. Thus, the aim of the present study was to conduct a systematic review of studies that analyze the reproductive aspects of freshwater teleosts in contaminated environments, focusing on the description of the toxic effects of pesticide residues on water capable of affecting the reproductive processes of bioindicator/biomonitor species.

\section{Material and methods}

The present review was based on systematized searches of scientific articles that address the topic "influence of environmental contaminants on the reproductive processes of freshwater fish". For this purpose, thorough searches were conducted in the main collection of the Web of Science database. To better focus the search, the following descriptors were used: fish reproduction, contamination, toxicology, ecotoxicity and biomonitoring. These terms were combined in a systematic search using the Boolean operators "AND" and "OR".

The criteria used for article selection included the type of aquatic environment, where only studies on freshwater fish species published between 2000 and 2019 were chosen. Using the 450,671 articles retrieved, a new search was conducted to filter only studies related to "fish reproduction", reducing the number of articles to 1,176. The 
articles that met the search criteria were organized in a spreadsheet in Microsoft Excel in chronological order for content analysis, initially performed by reading the titles and abstracts. A first screening was performed, reducing the number of articles from 1,176 to 98.

Next, content analysis of those 98 articles was performed through full reading of the articles, and only those that analyzed the toxic effect of contaminating substances in some of the reproductive stages in fish were selected, resulting in a final set of 40 articles analyzed in this study. The selected articles were consulted to prepare a table containing the main methods and results of each article (authors, year of publication, bioindicator species, contaminant, classification, biomonitoring method used and study site).

\section{Results and discussion}

Table 1 shows the data of the 40 selected articles that analyzed the toxic effects of pesticides on the reproductive process of freshwater teleosts, covering the period between 2000 and 2019.

Table 1. List of articles analyzed with possible effects of pesticide residues on the reproductive process of freshwater teleosts from the "Web of Science" database.

\begin{tabular}{|c|c|c|c|c|c|c|}
\hline Autor & $\begin{array}{l}\text { Bioindicator } \\
\text { species }\end{array}$ & Contaminant & Classification & $\begin{array}{c}\text { Degree of } \\
\text { exposured }\end{array}$ & $\begin{array}{c}\text { Mechanism } \\
\text { of action }\end{array}$ & Country \\
\hline Ankley et al. (2001) & $\begin{array}{l}\text { Pimephales } \\
\text { promelas }\end{array}$ & Methoxychlor & Insecticide & Acute & RED & EUA \\
\hline Moore et al. (2001) & Salmo salar & Cypermethrin & Insecticide & Acute & RED and ED & UK \\
\hline $\begin{array}{l}\text { Gormley and Teacher } \\
\text { (2003) }\end{array}$ & Oryzias latipes & Endosulfan & Insecticide & Acute & RED and ED & Canada \\
\hline Roex et al. (2003) & Danio rerio & Parathion & Insecticide & Chronic & RED & Netherlands \\
\hline Kleinkauf et al. (2004) & Platichthys flesus & $\begin{array}{c}\text { DDT and } \\
\text { Hexachlorobenze } \\
\text { ne }\end{array}$ & $\begin{array}{l}\text { Insecticide and } \\
\text { Fungicide }\end{array}$ & Chronic & RED & UK \\
\hline Chandra et al. (2004) & Cyprinus carpio & Carbofuran & Insecticide & Chronic & RED & India \\
\hline $\begin{array}{l}\text { Aydin and Köprücü } \\
(2005)\end{array}$ & Cyprinus carpio & Cypermethrin & Insecticide & Acute & ED & Turkey \\
\hline Ankley et al. (2005) & $\begin{array}{c}\text { Pimephales } \\
\text { promelas }\end{array}$ & $\begin{array}{c}\text { Prochloraze } \\
\text { fenarimol }\end{array}$ & Fungicide & Acute & RED & EUA \\
\hline Aydin et al. (2005) & Cyprinus carpio & Diazon & Insecticide & Acute & ED & Turkey \\
\hline Hanson et al. (2007) & $\begin{array}{c}\text { Oreochromis } \\
\text { niloticus } \\
\text { Clarias gariepinus } \\
\text { Chrysicthys } \\
\text { nigrodigitatus }\end{array}$ & $\begin{array}{c}\text { Lindano, } \\
\text { pentaclorofenol } \\
\text { (PCP) and } \\
\text { propoxur }\end{array}$ & Fungicide & Acute & GSI & Gana \\
\hline Ankley et al. (2007) & $\begin{array}{l}\text { Pimephales } \\
\text { promelas }\end{array}$ & Ketoconzole & Fungicide & Acute & RED & EUA \\
\hline Woo et al. (2008) & Oryzias latipes & Iprobenfos & Fungicide & Chronic & $\mathrm{GE}$ & Korea \\
\hline $\begin{array}{l}\text { Singh and Singh } \\
(2008)\end{array}$ & $\begin{array}{c}\text { Rita rita } \\
\text { Mystus tengara } \\
\text { Cyprinus carpio } \\
\text { Labeo rohita }\end{array}$ & $\begin{array}{c}\text { HCH, DDT, aldrina, } \\
\text { endosulfan and } \\
\text { Chlorpyrifos }\end{array}$ & Insecticide & Chronic & RED & India \\
\hline $\begin{array}{l}\text { Balasubramani et al. } \\
(2008)\end{array}$ & Danio rerio & Endosulfan & Insecticide & Chronic & RED & India \\
\hline Kim et al. (2008) & Oryzias latipes & $\begin{array}{c}\text { Cartap and } \\
\text { Cypermethrin }\end{array}$ & $\begin{array}{l}\text { Insecticide and } \\
\text { Fungicide }\end{array}$ & Acute & ED & Korea \\
\hline $\begin{array}{l}\text { Arellano-Aguilar et al. } \\
\text { (2009) }\end{array}$ & $\begin{array}{l}\text { Girardinichthys } \\
\text { multiradiatus }\end{array}$ & Parathion & Insecticide & Chronic & RED and ED & Mexico \\
\hline Edwards et al. (2010) & $\begin{array}{l}\text { Gambusia } \\
\text { holbrooki }\end{array}$ & $\begin{array}{l}\text { DDT, DDE and } \\
\text { bifenilos } \\
\text { policlorados } \\
\text { (PCBs) } \\
\end{array}$ & Insecticide & Chronic & RED & EUA \\
\hline
\end{tabular}


Table 1. Continued.

\begin{tabular}{|c|c|c|c|c|c|c|}
\hline Autor & $\begin{array}{c}\text { Bioindicator } \\
\text { species }\end{array}$ & Contaminant & Classification & $\begin{array}{c}\text { Degree of } \\
\text { exposured }\end{array}$ & $\begin{array}{c}\text { Mechanism } \\
\text { of action }\end{array}$ & Country \\
\hline Veldhoen et al. (2010) & $\begin{array}{c}\text { Oncorhynchus } \\
\text { nerka } \\
\text { Oncorhynchus } \\
\text { tshawytscha }\end{array}$ & $\begin{array}{l}\text { Octacloroestirene, } \\
\text { clorobenzenos, } \\
\text { DDTs, HCHs and } \\
\text { ciclodienos }\end{array}$ & Insecticide & Chronic & GE & Canada \\
\hline Piazza et al. (2011) & $\begin{array}{c}\text { Cichlasoma } \\
\text { dimerus }\end{array}$ & Endosulfan & Insecticide & Chronic & RED & Argentina \\
\hline Han et al. (2011) & $\begin{array}{c}\text { Cichlasoma } \\
\text { dimerus }\end{array}$ & Endosulfan & Insecticide & Acute & RED & Argentina \\
\hline Cuña et al. (2011) & $\begin{array}{l}\text { Cichlasoma } \\
\text { dimerus }\end{array}$ & Endosulfan & Insecticide & Acute & $\mathrm{GH}$ & Argentina \\
\hline Montanha et al. (2012) & Rhamdia quelen & $\begin{array}{c}\text { Cypermethrin and } \\
\text { deltametrin }\end{array}$ & Insecticide & Acute & ED & Brazil \\
\hline Beyger et al. (2012) & Jordanella floridae & Endosulfan & Insecticide & $\begin{array}{l}\text { Acute/ } \\
\text { chronic }\end{array}$ & ED & Canada \\
\hline Bencic et al. (2013) & $\begin{array}{l}\text { Pimephales } \\
\text { promelas }\end{array}$ & Fipronil & Insecticide & Chronic & RED & EUA \\
\hline Cuña et al. (2013) & $\begin{array}{l}\text { Cichlasoma } \\
\text { dimerus }\end{array}$ & Endosulfan & Insecticide & Chronic & RED and GH & Germany \\
\hline Barni et al. (2014) & $\begin{array}{l}\text { Odontesthes } \\
\text { bonariensis }\end{array}$ & $\begin{array}{c}\text { Endosulfan and } \\
\text { DDT }\end{array}$ & Insecticide & Chronic & RED & Germany \\
\hline Vincze et al. (2014) & Danio rerio & $\begin{array}{l}\text { Tetrametil } \\
\text { decynediol }\end{array}$ & Herbicide & Acute & ED & Germany \\
\hline $\begin{array}{l}\text { Uren-Webster et al. } \\
(2014)\end{array}$ & Danio rerio & Glyphosate & Herbicide & Acute & $\begin{array}{c}\text { Oxidative } \\
\text { stress }\end{array}$ & UK \\
\hline Piazza et al. (2015) & $\begin{array}{l}\text { Cichlasoma } \\
\text { dimerus }\end{array}$ & Endosulfan & Insecticide & Chronic & RED & Argentina \\
\hline Cuña et al. (2016) & $\begin{array}{l}\text { Cichlasoma } \\
\text { dimerus }\end{array}$ & Endosulfan & Insecticide & Acute & RED & Argentina \\
\hline Ma et al., (2016) & Danio rerio & Azocyclotin & Fungicide & Chronic & RED & China \\
\hline Garayzar et al. (2016) & Danio rerio & Clorotalonil & Fungicide & Chronic & GE & Canada \\
\hline $\begin{array}{l}\text { Martyniuk et al. } \\
(2016)\end{array}$ & $\begin{array}{l}\text { Micropterus } \\
\text { salmoides }\end{array}$ & Methoxychlor & Insecticide & Chronic & GE & EUA \\
\hline Kutluyer et al. (2016) & $\begin{array}{l}\text { Oncorhynchus } \\
\text { mykiss }\end{array}$ & Cypermethrin & Insecticide & Acute & $\begin{array}{c}\text { Oxidative } \\
\text { stress and } \\
\text { sperm } \\
\text { quality }\end{array}$ & Turkey \\
\hline Marcon et al. (2015) & $\begin{array}{c}\text { Astyanax } \\
\text { bimaculatus }\end{array}$ & Endosulfan & Insecticide & Acute & $\mathrm{GH}$ & Brazil \\
\hline Sumon et al. (2016) & $\begin{array}{l}\text { Trichogaster } \\
\text { fasciata }\end{array}$ & Chlorpyrifos & Insecticide & Acute & ED & Netherlands \\
\hline Flynn et al. (2018) & Oryzias latipes & Diazon & Insecticide & Chronic & RED & EUA \\
\hline $\begin{array}{l}\text { Glaberman et al. } \\
\text { (2019) }\end{array}$ & $\begin{array}{c}\text { Pimephales } \\
\text { promelas } \\
\text { Oncorhynchus } \\
\text { mykiss }\end{array}$ & Propiconazol & Fungicide & Chronic & RED & EUA \\
\hline Xiang et al. (2019) & Danio rerio & Cis-Bifenthrin & Insecticide & Chronic & RED & EUA \\
\hline Sumon et al. (2019) & $\begin{array}{l}\text { Trichogaster } \\
\text { fasciata }\end{array}$ & Chlorpyrifos & Insecticide & Chronic & HG e GSI & Bangladesh \\
\hline
\end{tabular}

Legends: $\mathrm{ED}=$ embryonic development; $\mathrm{GE}=$ gene expression; $\mathrm{GH}$ = gonadal histopathology; $\mathrm{GSI}=$ gonadosomatic index; RED = reproductive endocrine disorders.

Subsequent analyses revealed toxicological studies with teleost fish models, addressing the bioindicator species used as well as the contaminant and its classification, in addition to the degree of exposure in the tests performed in each of the studies (acute or chronic), also emphasizing the mechanisms of action by which the contaminants influenced the reproductive processes indicated. In general, it was possible to classify 3 classes of pesticides (insecticides, fungicides, and herbicides) and 7 mechanisms of action: reproductive endocrine disorders (REDs), gene expression (GE), oxidative stress, gonadal 
histopathology (GH), gonadosomatic index (GSI), sperm quality, and embryonic development (ED).

The reproductive strategies and mechanisms in fish can be directly influenced by several changes in local abiotic characteristics, such as industrial, urban, and agricultural pollution (Lowe-McConnell, 1999). Year after year, the chronic effects of pesticide toxicity in teleosts cause behavioral changes, reduced growth rates, neurological damage, histopathological changes (in gills, liver, and hematopoietic and endocrine tissues) and reproductive disorders (Sabra and Mehana, 2015).

A total of 24 fish species were recorded (Figure 1) and Danio rerio (Hamilton, 1822) was the most analyzed, occurring in $17.5 \%$ of the studies, followed by Cichlasoma dimerus (Heckel, 1840) (15\%), Pimephales promelas Rafinesque, 1820 (12.5\%), and Oryzias latipes (Temminck and Schlegel, 1846) (10\%). Characteristics shared by these species include reduced size, short life cycle and split spawning.

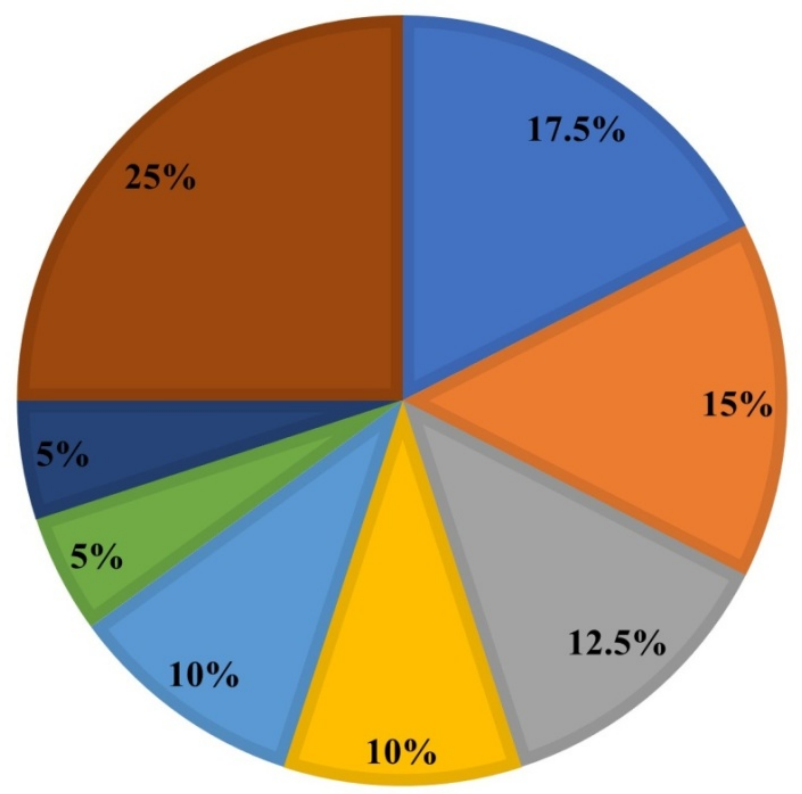

Danio rerio

Cichlasoma dimerus

- Pimephales promelas

Oryzias latipes

Cyprinus carpio

Oncorhynchus mykiss

- Trichogaster fasciata

- Others

Figure 1. Main species used in toxicological studies of pesticides in fish reproductive systems.

In general, small-sized fish with short reproductive cycles, such as those most used in the studies described here, have been targeted in analyses and the development of specific protocols for toxicological tests that evaluate the potential of a chemical to negatively affect fish through endocrine dysregulation, mainly associated with reproduction but also secondarily by affecting growth, development, and survival (USEPA, 2009; Flynn et al., 2018). However, native species that are already being used in studies with biomarkers of aquatic contamination, such as tambaqui Colossoma macropomum (Cuvier, 1816) (Carvalho-Neta et al., 2015), do not appear in the studies analyzed here that focus on the effects of pesticide residues on reproductive processes. Although it is not a small species and has a single spawning event, studies with this and other species that occur naturally in environments impacted by agricultural pesticides are important for evaluating the real effects of contaminants on animal health and the continuity of natural stock renewal. 
Of the total contaminants found, $78 \%$ were classified as insecticides, $18 \%$ as fungicides and $5 \%$ as herbicides (Figure 2), based on the descriptions in the articles analyzed. The pesticides most studied in toxicological tests of fish reproductive systems were endosulfan (35\%), cypermethrin and DDT (13\%) and HCH (8\%). Endosulfan is recognized as one of the most dangerous organochlorine pesticides, as are DDT and $\mathrm{HCH}$, and is widely used in several countries as a broad-spectrum insecticide for commercial plantations, with India and Israel as the main producers (Cuña et al., 2013). Once in contact with the aquatic biota, Endosulfan can affect the normal regulation of numerous biological processes, including fish reproduction (Han et al., 2011), acting as an endocrine disruptor, which affects hormonal regulation and thus causes reproductive disorders (Cuña et al., 2016). In turn, cypermethrin, a type II synthetic pyrethroid insecticide with high efficiency and low residual power with low toxicity for mammals and birds, is also part of the group of pesticides with great toxic potential in fish due to slower metabolism and elimination in fish than in other vertebrates (Moore et al., 2001; Montanha et al., 2012; Kutluyer et al., 2016).

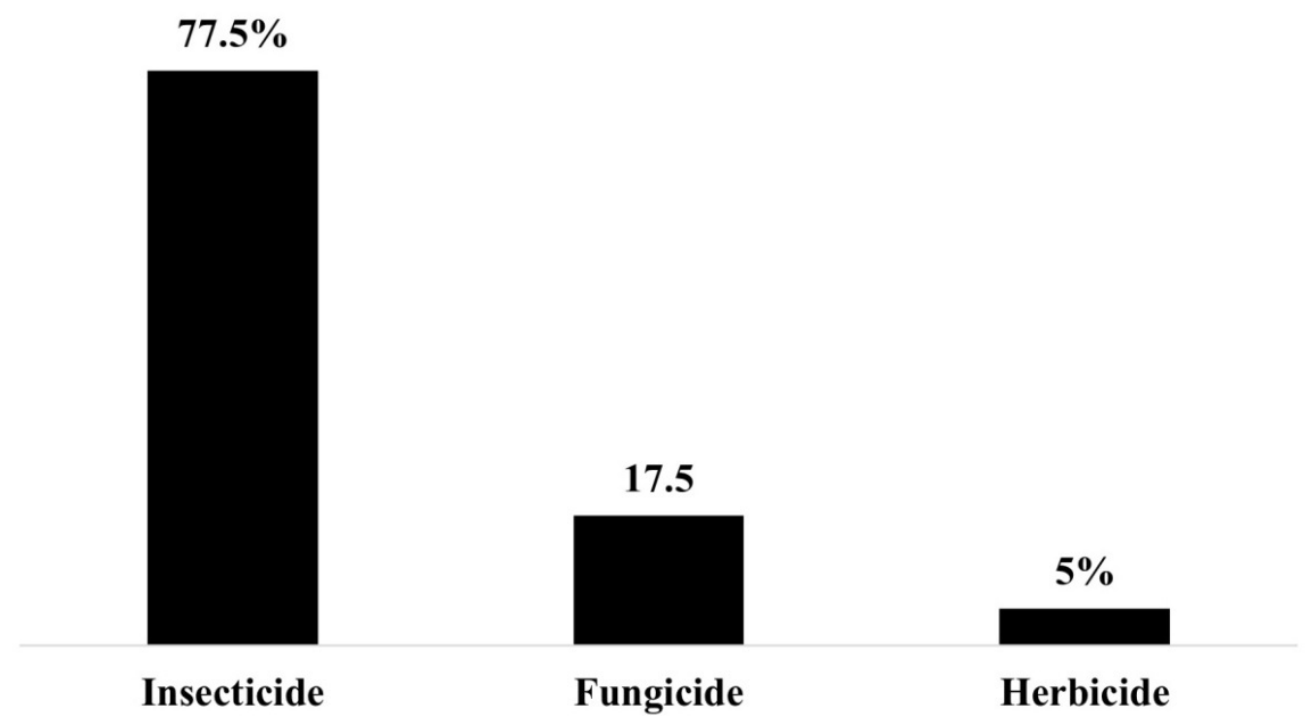

Figure 2. Classification of the most found pesticides according to the description present in the analyzed articles.

The mechanisms of action of the pesticides show effects at different levels of toxicity, with reproductive endocrine disorders being the most reported in more than $50 \%$ of the analyzed studies. According to Sabra and Mehana (2015), fish exposed to environmental pollutants such as insecticides, herbicides, heavy metals and xenobiotics may suffer disturbances in their natural reproductive processes, potentially resulting in changes such as decreased fertility and histological damage in the testes and in the ovaries (Cuña et al., 2011, 2013; Marcon et al., 2015), impairment of the vitellogenesis process and interruption of the steroidogenesis process (Singh and Singh, 2008), delayed maturation of the gonads evidenced by changes in the gonadosomatic index (Kleinkauf et al., 2004; Sumon et al., 2019), changes in reproductive and parental behavior, impaired olfactory response and consequent disturbance of reproductive migrations, and disturbances in the 
coordination between the courtship behavior of male and female fish and spawning time (Jaensson et al., 2007).

According to Garayzar et al. (2016), when analyzing the effect of chlorothalonil on gene expression in Danio rerio, there are changes in transcriptional networks associated with reproduction, such as stages that included fertilization, male reproduction, and testicular function, after exposure of fish to pesticides. Similar effects were observed by Xiang et al. (2019), who correlated changes in the expression of key genes associated with the endocrine pathways of the reproductive system of Danio rerio after exposure to cisbifenthrin, also inferring a reduction in the total motility rate of spermatozoa. Han et al. (2011) observed intratesticular sperm necrosis in Danio rerio after exposure to endosulfan, suggesting that the reductions identified in fertilization rates after prolonged exposures could be due to testicular and sperm damage.

The use of gametes in toxicological bioassays has still been little used in evaluations of the deleterious effects on the reproductive processes of fish exposed to contaminants (Losso et al., 2007; Mamindy-Pajany et al., 2010). In an acute test study evaluating the toxic effect of cypermethrin on the motility rate and duration of motility in rainbow trout Oncorhynchus mykiss (Walbaum, 1792) sperm, the authors observed a high sensitivity of sperm cells to low concentrations of the pesticide (Kutluyer et al., 2016). Fabbrocini et al. (2012) analyzed the feasibility of using cryopreserved sperm cells from Sparus aurata in ecotoxicological tests in which sperm cells exposed to cadmium showed significant differences after 2 hours of exposure to the contaminant. Typically, toxicological tests use methodologies that subject a model organism to various concentrations of a chemical over a relatively long period to replicate conditions of chronic exposure (Gormley and Teacher, 2003). However, in many cases of runoff events after heavy rainfall, chemicals can remain in the environment for a short period, requiring an increase in short-term toxicological tests.

The evaluations of parameters that characterize sperm quality, such as motility, are fast and easy to perform, require small sample volumes for testing and do not require specially equipped facilities because they can even be performed as part of field monitoring programs. When cryopreserved, semen can be easily stored and transferred (Maria and Carneiro, 2012; Salmito-Vanderley et al., 2016), allowing numerous opportunities to evaluate samples in future toxicological tests at a time and place based on the needs of the researchers, thus allowing a better standardization strategy for the biomonitoring in contaminated environments (Fabbrocini et al., 2012).

\section{Conclusion}

The effects of pesticides on the reproductive processes of freshwater teleost fish are evident, mainly causing endocrine reproductive disorders, morphological changes in the gonads and a decrease in the quality of gametes. Although the toxic effects of pesticides are often not observed at levels that cause immediate changes in humans, bioaccumulation can be a risk factor for a portion of the population that feed on fish. The indiscriminate use of pesticides by the agricultural sector, especially insecticides such as Endosulfan and cypermethrin and those belonging to the dichlorodiphenyltrichloroethane group, can lead to a drastic reduction in the renewal of natural fish stocks in rivers and lakes, which may result in the loss of biodiversity.

Therefore, specific studies using native fish species are essential for defining adequate protocols to be applied by regulatory institutions in requests for the release and use of pesticides in agriculture, with a specific focus on analyses of sperm quality in fish, considering that such assays involve low-cost technique and can be executed in a short period of time. 
Understanding the toxic effects and the stages of the biological cycle of nontarget species in toxicological tests can lead to discussions for the better management of water with multiple uses, particularly for greater effectiveness in the conservation of the aquatic environment.

\section{Acknowledgements}

We thank Coordenação de Aperfeiçoamento de pessoal de Nível Superior (CAPES), Finance Code 001, and Universidade Estadual do Maranhão (UEMA), for providing the scholarship to (SJMA), under the process (001), and Fundação de Amparo à Pesquisa e ao Desenvolvimento Científico e Tecnológico do Maranhão (FAPEMA, APP-UNIVERSAL$002877 / 2020$ ) to JPS. We would like to thank AJE for English language editing.

\section{Conflicts of interest}

The authors declare that have no conflicts of interest.

\section{References}

Ankley, G. T.; Jensen, K. M.; Durhan, E. J.; Makynen, E. A.; Butterworth, B. C.; Kahl, M. D.; Villeneuve, D. L.; Linnum, A.; Gray, L. E.; Cardon, M.; Wilson, V. S. Effects of two fungicides with multiple modes of action on reproductive endocrine function in the fathead minnow (Pimephales promelas). Toxicological Sciences, v. 86, no. 2, p. 300-308, 2005. https://doi.org/10.1093/toxsci/kfi202

Ankley, G. T.; Jensen, K. M.; Kahl, M. D.; Korte, J. J.; Makynen, E. A. Description and evaluation of a short-term reproduction test with the fathead minnow (Pimephales promelas). Environmental Toxicology and Chemistry, v. 20, no. 6, p. 1276-1290, 2001. https://doi.org/10.1002/etc.5620200616

Ankley, G. T.; Jensen, K. M.; Kahl, M. D.; Makynen, E. A.; Blake, L. S.; Greene, K. J.; Johnson, R. D.; Villeneuve, D. L. Ketoconazole in the fathead minnow (Pimephales promelas): Reproductive toxicity and biological compensation. Environmental Toxicology and Chemistry, v. 26, no. 6, 1214, 2007. https://doi.org/10.1897/06-428R.1

Arellano-Aguilar, O.; Garcia, C. M. Effects of methyl parathion exposure on development and reproduction in the viviparous fish Girardinichthys multiradiatus. Environmental Toxicology, v. 24, no. 2, p. 178-186, 2009. https://doi.org/10.1002/tox.20414

Aydin, R.; Köprücü, K. Acute toxicity of diazinon on the common carp (Cyprinus carpio L.) embryos and larvae. Pesticide Biochemistry and Physiology, v. 82, no. 3, p. 220-225, 2005. https://doi.org/10.1016/j.pestbp.2005.03.001

Aydin, R.; Köprücü, K.; Dörücü, M.; Köprücü, S. Ş.; Pala, M. Acute toxicity of synthetic pyrethroid cypermethrin on the common carp (Cyprinus carpio L.) embryos and larvae. Aquaculture International, v. 13, no. 5, p.451-458, 2005. https://doi.org/10.1007/ s10499-005-0615-5

Balasubramani, A.; Pandian, T. J. Endosulfan suppresses growth and reproduction in zebrafish. Current Science, v. 94, no. 7, p. 883-890, 2008.

Barni, M. F.; Gonzalez, M.; Miglioranza, K. S. B. Assessment of persistent organic pollutants accumulation and lipid peroxidation in two reproductive stages of wild silverside (Odontesthes bonariensis). Ecotoxicology and Environmental Safety, v. 99, p. 45-53, 2014. https://doi.org/10.1016/j.ecoenv.2013.10.012 
Begum G. Carbofuran insecticide induced biochemical alterations in liver and muscle tissues of the fish Clarias batrachus (Linn) and recovery response. Aquatic Toxicology, v. 66, p. 83-92, 2004. https://doi.org/10.1016/j.aquatox.2003.08.002

Bencic, D. C.; Villeneuve, D. L.; Biales, A. D.; Blake, L.; Durhan, E. J.; Jensen, K. M.; Kahl, M. D.; Makynen, E. A.; Martinović-Weigelt, D.; Ankley, G. T. Effects of the insecticide fipronil on reproductive endocrinology in the fathead minnow. Environmental Toxicology and Chemistry, v. 32, no. 8, p. 1828-1834, 2013. https://doi.org/10.1002/etc.2254

Beyger, L.; Orrego, R.; Guchardi, J.; Holdway, D. The acute and chronic effects of endosulfan pulse-exposure on Jordanella floridae (Florida flagfish) over one complete lifecycle. Ecotoxicology and Environmental Safety, v.76, p.71-78, 2012. https://doi.org/ 10.1016/j.ecoenv.2011.09.015

Carvalho Neta, R. N. F.; Sousa, D. B. P.; Macêdo Sobrinho, I. C.; Horton, E. Y.; Almeida, Z. S.; Tchaicka, L.; Sousa, A. L. Genotoxic and hematological parameters in Colossoma macropomum (Pisces, Serrasalmidae) as biomarkers for environmental impact assessment in a protected area in Northeastern Brazil. Environmental Science and Pollution Research International, v. 22, p. 15994-16003, 2015. https://doi.org/10.1007/s11356015-4748-4

Chandra, S.; Ram, R. N.; Singh, I. J. First ovarian maturity and recovery response in common carp, Cyprinus carpio after exposure to carbofuran. Journal of Environmental Biology, v. 25, no. 3, p. 239-249, 2004.

Costa, C. R.; Olivi, P.; Botta, C. M. R.; Espindola, E. L. G. A toxicidade em ambientes aquáticos: discussão e métodos de avaliação. Química Nova, v. 31, no. 7, p. 1820-1830, 2008. https://doi.org/10.1590/S0100-40422008000700038

Cuña, R. H.; Pandolfi, M.; Genovese, G.; Piazza, Y.; Ansaldo, M.; Lo Nostro, F. L. Endocrine disruptive potential of endosulfan on the reproductive axis of Cichlasoma dimerus (Perciformes, Cichlidae). Aquatic Toxicology, v.126, p.299-305, 2013. https://doi.org/10.1016/j.aquatox.2012.09.015

Cuña, R. H.; Vázquez, G. R.; Dorelle, L.; Rodríguez, E. M.; Guimarães, M. R.; Lo Nostro, F. L. Mechanism of action of endosulfan as disruptor of gonadal steroidogenesis in the cichlid fish Cichlasoma dimerus. Comparative Biochemistry and Physiology Part C: Toxicology \& Pharmacology, v. 187, p. 74-80, 2016. https://doi.org/10.1016/j.cbpc.2016.05.008

Cuña, R. H.; Vázquez, G. R.; Piol, M. N.; Guerrero, N. V.; Maggese, M. C.; Lo Nostro, F. L. Assessment of the acute toxicity of the organochlorine pesticide endosulfan in Cichlasoma dimerus (Teleostei, Perciformes). Ecotoxicology and Environmental Safety, v. 74, no. 4, p. 1065-1073, 2011. https://doi.org/10.1016/j.ecoenv.2011.02.002

Daouk, T.; Larcher, T.; Roupsard, F.; Lyphout, L.; Rigaud, C.; Ledevin, M.; Loizeau, V.; Cousin, X. Long-term food-exposure of zebrafish to PCB mixtures mimicking some environmental situations induces ovary pathology and impairs reproduction ability. Aquatic Toxicology, v. 105, no. 3/4, p. 270-278, 2011. https://doi.org/10.1016/ j.aquatox.2011.06.021

Edwards, T. M.; Toft, G.; Guillette, L. J. Seasonal reproductive patterns of female Gambusia holbrooki from two Florida lakes. Science of The Total Environment, v. 408, no. 7, p. 1569-1576, 2010. https://doi.org/10.1016/j.scitotenv.2009.12.013 
Fabbrocini, A.; D’Adamo, R.; Del Prete, F.; Langellotti, A. L.; Rinna, F.; Silvestri, F.; Sorrenti, G.; Vitiello, V.; Sansone, G. Cryopreserved semen in ecotoxicological bioassays: Sensitivity and reliability of cryopreserved Sparus aurata spermatozoa. Ecotoxicology and Environmental Safety, v. 84, p. 293-298, 2012. https://doi.org/10.1016/ j.ecoenv.2012.07.024

FAO - Food and Agriculture Organization of the United Nations. The state of world fisheries and aquaculture (SOFIA). Rome: FAO, 2020. https://doi.org/ $10.4060 /$ ca9229en

Flynn, K.; Lothenbach, D.; Whiteman, F.; Hammermeister, D.; Swintek, J.; Etterson, M.; Johnson, R. The effects of continuous diazinon exposure on growth and reproduction in Japanese medaka using a modified Medaka Extended One Generation Reproduction Test (MEOGRT). Ecotoxicology and Environmental Safety, v. 162, p. 438-445, 2018. https://doi.org/10.1016/j.ecoenv.2018.06.088

Fricke, R.; Eschmeyer, W. N.; Fong, J. D. Genera/species by family/subfamily in Eschmeyer's Catalog of Fishes. 2020. Available from: <http://researcharchive.calacademy. org/research/ichthyology/catalog/SpeciesByFamily.asp>. Accessed on: May 02, 2021.

Garayzar, A. B. S.; Bahamonde, P. A.; Martyniuk, C. J.; Betancourt, M.; Munkittrick, K. R. Hepatic gene expression profiling in zebrafish (Danio rerio) exposed to the fungicide chlorothalonil. Comparative Biochemistry and Physiology Part D: Genomics and Proteomics, v. 19, p. 102-111, 2016. https://doi.org/10.1016/j.cbd.2016.04.004

Glaberman, S.; Kiwiet, J.; Aubee, C. B. Evaluating the role of fish as surrogates for amphibians in pesticide ecological risk assessment. Chemosphere, v. 235, p. 952-958, 2019. https://doi.org/10.1101/584417

Gormley, K. L.; Teather, K. L. Developmental, behavioral, and reproductive effects experienced by Japanese medaka (Oryzias latipes) in response to short-term exposure to endosulfan. Ecotoxicology and Environmental Safety, v 54, no 3, p. 330-338, 2003. https://doi.org/10.1016/S0147-6513(02)00005-2

Han, Z.; Jiao, S.; Kong, D.; Shan, Z.; Zhang, X. Effects of $\beta$-endosulfan on the growth and reproduction of zebrafish (Danio rerio). Environmental Toxicology and Chemistry, v. 30, no 11, p. 2525-2531, 2011. https://doi.org/10.1002/etc.646

Hanson, R.; Dodoo, D. K.; Essumang, D. K.; Blay, J.; Yankson, K. The effect of some selected pesticides on the growth and reproduction of fresh water Oreochromis niloticus, Chrysicthys nigrodigitatus and Clarias gariepinus. Bulletin of Environmental Contamination and Toxicology, v 79, no. 5, p. 544-547, 2007. https://doi.org/10.1007/ s00128-007-9279-3

Jaensson, A.; Scott, A. P.; Moore, A.; Kylin, H.; Olsén, K. H. Effects of a pyrethroid pesticide on endocrine responses to female odours and reproductive behaviour in male parr of brown trout (Salmo trutta L.). Aquatic Toxicology, v. 81, no. 1, p.1-9, 2007. https://doi.org/10.1016/j.aquatox.2006.10.011

Jones, J.; Reynolds, J. D. Effects of pollution on reproductive behaviour of fishes. Reviews in Fish Biology and Fisheries, v. 7, p. 463-491, 1997. https://doi.org/10.1023/ A:1018456315671

Kim, Y.; Jung, J.; Oh, S.; Choi, K. Aquatic toxicity of cartap and cypermethrin to different life stages of Daphnia magna and Oryzias latipes. Journal of Environmental Science and Health Part B, v. 43, p. 56-64, 2008. https://doi.org/10.1080/03601230701735029 
Kleinkauf, A.; Connor, L.; Swarbreck, D.; Levene, C.; Walker, P.; Johnson, P. J.; Leah, R. T. General condition biomarkers in relation to contaminant burden in European flounder (Platichthys flesus). Ecotoxicology and Environmental Safety, v. 58, no. 3, p. 335-355, 2004. https://doi.org/10.1016/j.ecoenv.2004.03.007

Kutluyer, F.; Benzer, F.; Erişir, M.; Öğretmen, F.; İnanan, B. E. The in vitro effect of cypermethrin on quality and oxidative stress indices of rainbow trout Oncorhynchus mykiss spermatozoa. Pesticide Biochemistry and Physiology, v. 128, p. 63-67, 2016. https://doi.org/10.1016/j.pestbp.2015.10.001

Lima, L. B. D.; Morais, P. B.; Andrade, R. L. T.; Mattos, L. V.; Moron, S. E. Use of biomarkers to evaluate the ecological risk of xenobiotics associated with agriculture. Environmental Pollution, v. 237, p. 611-624, 2018. https://doi.org/10.1016/j.envpol.2018.02.011

Lins, J. A. P. N.; Kirschnik, P. G.; Queiroz, V. S.; Cirio, S. M. Uso de peixes como biomarcadores para monitoramento ambiental aquático. Revista Acadêmica de Ciências Agrárias e Ambientais, v. 8, no. 4, p. 469-484, 2010. https://doi.org/10.7213/ cienciaanimal.v8i4.11018

Losso, C.; Picone, M.; Novelli, A. A.; Delaney, E.; Ghetti, P. F.; Ghirardini, A. V. Developing toxicity scores for embryotoxicity tests on elutriates with the sea urchin Paracentrotus lividus, the oyster Crassostrea gigas, and the mussel Mytilus galloprovincialis. Archives of Environmental Contamination and Toxicology, v. 53, p. 220-226, 2007. https://doi.org/10.1007/s00244-006-0136-x

Lowe-Mcconnell, R. H. Estudos ecológicos de comunidades de peixes tropicais. São Paulo: EDUSP, 1999.

Ma, Y. N.; Cao, C. Y.; Wang, Q. W.; Gui, W. J.; Zhu, G. N. Effects of azocyclotin on gene transcription and steroid metabolome of hypothalamic pituitary gonad axis, and their consequences on reproduction in zebrafish (Danio rerio). Aquatic Toxicology, v. 179, p. 55-64, 2016. https://doi.org/10.1016/j.aquatox.2016.08.006

Mamindy-Pajany, Y.; Libralato, G.; Roméo, M.; Hurel, C.; Losso, C.; Ghirardini, A. V.; Marmier, N. Ecotoxicological evaluation of Mediterranean dredged sediment ports based on elutriates with oyster embryotoxicity tests after composting process. Water Resistence, v. 44, p. 1986-1994, 2010. https://doi.org/10.1016/j.watres.2009.11.056

Marcon, L.; Mounteer, A. H.; Bazzoli, N.; Benjamin, L. A. Effects of insecticide Thiodan $®$ on the morphology and quantification of ovarian follicles in lambaris Astyanax bimaculatus (Linnaeus, 1758) in different treatments. Aquaculture Research, v. 47, no. 8, p. 2407-2418, 2015. https://doi.org/10.1111/are.12687

Maria, N. A.; Carneiro, P. C. F. Criopreservação de sêmen de peixes no Brasil: estado da arte e perspectivas futuras. Ciência Animal, v. 22, no. 1, p. 124-131, 2012.

Marques, M. B. L.; Américo-Pinheiro, J. H. P. Ocorrência de clorpirifós em ambientes aquáticos e seus efeitos ecotoxicológicos em bioindicadores. Revista Nacional de Gerenciamento de Cidades, v. 8, n. 65, 2020. https://doi.org/10.17271/ 2318847286520202734

Martyniuk, C. J.; Doperalski, N. J.; Prucha, M. S.; Zhang, J. L.; Kroll, K. J.; Conrow, R.; Barber, D. S.; Denslow, N. D. High contaminant loads in Lake Apopka's riparian wetland disrupt gene networks involved in reproduction and immune function in largemouth bass. Comparative Biochemistry and Physiology Part D: Genomics and Proteomics, v. 19, p. 140-150, 2016. https://doi.org/10.1016/j.cbd.2016.06.003 
Massaro, F. C. Estudos ecotoxicológicos com Hydra viridissima (Cnidaria: Hydrozoa). São Carlos: Universidade de São Paulo, 2006. (Master dissertation).

Mondal, K.; Karmakar, B.; Haque, S. A review on effects of pyrethroids pesticides on freshwater fish behaviour and fish reproduction. Journal of Global Bioscience, v. 4, no. 6, p. 2594-2598, 2015.

Montanha, F. P.; Galeb, L. A. G.; Mikos, J. D.; Ganeco, L. N.; Pereira, T. P.; Tanaka, A.; Kirschnik, P. G.; Pimpão, C. T. Pyrethroid toxicity in silver catfish, Rhamdia quelen. Pesquisa Veterinária Brasileira, v. 32, no. 12, p. 1297-1303, 2012. https://doi.org/ 10.1590/S0100-736X2012001200014

Moore, A.; Waring, C. P. The effects of a synthetic pyrethroid pesticide on some aspects of reproduction in Atlantic salmon (Salmo salar L.). Aquatic Toxicology, v. 52, no. 1, p. 1-12, 2001. https://doi.org/10.1016/S0166-445X(00)00133-8

Paschoalini, A. L.; Savassi, L. A.; Arantes, F. P.; Rizzo, E.; Bazzoli, N. Heavy metals accumulation and endocrine disruption in Prochilodus argenteus from a polluted neotropical river. Ecotoxicology and Environmental Safety, v. 169, p. 539-550, 2019. https://doi.org/10.1016/j.ecoenv.2018.11.047

Piazza, Y. G.; Pandolfi, M.; Lo Nostro, F. L. Effect of the organochlorine pesticide endosulfan on GnRH and gonadotrope cell populations in fish larvae. Archives of Environmental Contamination and Toxicology, v. 61, no 2, p. 300-310, 2010. https://doi.org/10.1007/ s00244-010-9621-3

Piazza, Y.; Pandolfi, M.; Cuña, R.; Genovese, G.; Lo Nostro, F. Endosulfan affects GnRH cells in sexually differentiated juveniles of the perciform Cichlasoma dimerus. Ecotoxicology and Environmental Safety, v. 116, p.150-159, 2015. https://doi.org/10.1016/ j.ecoenv.2015.03.013

Pinto, A. C.; Marques, L. H. B. S.; Santos, F. L. B. Use of bioassay in ecotoxicological evaluation of urban lakes (Paulo Afonso/BA) with Poecilia reticulata (Peters, 1859) (Chordata: Teleostei). Brazilian Journal of Animal and Environmental Research, v. 3, no. 3, p. 1297-1313, 2020. https://doi.org/10.34188/bjaerv3n3-048

Prasad, M.; Kumar, A.; Mishra, D.; Srivastav, S. K.; Srivastav, A. K. Alterations in blood electrolytes of a freshwater catfish Heteropneustes fossilis in response to treatment with a botanical pesticide, Nerium indicum leaf extract. Fish Physiology and Biochemistry, v. 37, no. 3, p. 505-510, 2010. https://doi.org/10.1007/s10695-010-9452-1

Ribeiro, N. U. F.; Américo-Pinheiro, J. H. P. Peixes como bioindicadores de agrotóxicos em ambientes aquáticos. Fórum Ambiental, v. 14, p. 846-856, 2018.

Rodrigues, G. Z. P.; Machado, A. B.; Gehlen, G. Influência de metais no comportamento reprodutivo de peixes, revisão bibliográfica. Revista Geama, v. 5, no. 1, p. 4-13, 2019.

Roex, E. W. M.; Keijzers, R.; Van Gestel, C. A. M. Acetylcholinesterase inhibition and increased food consumption rate in the zebrafish, Danio rerio, after chronic exposure to parathion. Aquatic Toxicology, v. 64, no. 4, p.451-460, 2003. https://doi.org/10.1016/ s0166-445X(03)00100-0

Sabra, F. S.; Mehana, E. S. E. D. Pesticides toxicity in fish with particular reference to insecticides. Asian Journal of Agriculture and Food Sciences, v. 3, no. 1, p. 40-60, 2015.

Salmito-Vanderley, C. S. B.; Almeida-Monteiro, O. S.; Nascimento, R. V. Tecnologia de conservação de sêmen de peixes: resfriamento, congelação e uso de antioxidantes. Revista Brasileira de Reprodução Animal, v. 40, no. 4, p. 194-199, 2016.

Rev. Bras. Gest. Amb. Sustent., 2021, vol. 8, n. 19, p. 1155-1168. 
Singh, P. B.; Singh, V. Pesticide bioaccumulation and plasma sex steroids in fishes during breeding phase from North India. Environmental Toxicology and Pharmacology, v. 25, no. 3, p. 342-350. 2008. https://doi.org/10.1016/j.etap.2007.11.003

Sumon, K. A.; Saha, S.; Van Den Brink, P. J.; Peeters, E. T. H. M.; Bosma, R. H.; Rashid, H. Acute toxicity of chlorpyrifos to embryo and larvae of banded gourami Trichogaster fasciata. Journal of Environmental Science and Health, Part B, v. 52, no. 2, p. 92-98, 2016. https://doi.org/10.1080/03601234.2016.1239979

Sumon, K. A.; Yesmin, M. F.; Van Den Brink, P. J.; Bosma, R. H.; Peeters, E. T. H. M.; Rashid, $\mathrm{H}$. Effects of long-term chlorpyrifos exposure on mortality and reproductive tissues of banded gourami (Trichogaster fasciata). Journal of Environmental Science and Health, Part B, v. 54, no 7, p. 549-559, 2019. https://doi.org/10.1080/03601234.2019.1614399

USEPA - United States Environmental Protection Agency. Test guidelines OPPTS 890.1350: Fish short-term reproduction assay. Endocrine Disruptor Screening Program Environmental Protection Agency - Prevention Pesticides and Toxic Substances, EPA 740C-09-007. 2009.

Veldhoen, N.; Ikonomou, M. G.; Dubetz, C.; MacPherson, N.; Sampson, T.; Kelly, B. C.; Helbing, C. C. Gene expression profiling and environmental contaminant assessment of migrating Pacific salmon in the Fraser River watershed of British Columbia. Aquatic Toxicology, v. 97, no 3, p. 212-225, 2010. https://doi.org/10.1016/j.aquatox.2009.09.009

Vincze, K.; Gehring, M.; Braunbeck T. (Eco)toxicological effects of 2,4,7,9-tetramethyl-5decyne-4,7-diol (TMDD) in zebrafish (Danio rerio) and permanent fish cell cultures. Environmental Science and Pollution Research, v. 21, no. 13, p. 8233-8241, 2014. https://doi.org/10.1007/s11356-014-2806-y

Webster, T. M. U.; Laing, L. V.; Florance, H.; Santos, E. M. Effects of glyphosate and its formulation, Roundup, on reproduction in zebrafish (Danio rerio). Environmental Science \& Technology, v. 48, no. 2, p.1271-1279, 2013. https://doi.org/10.1021/ es404258h

Woo, S. O.; Son, S. H.; Ryu, J.-C.; Yum, S. Gene expression profile in iprobenfos exposed medaka fish by microarray analysis. Molecular \& Cellular Toxicology, v. 4, no. 2, p. 132$137,2008$.

Xiang, D.; Zhong, L.; Shen, S.; Song, Z.; Zhu, G.; Wang, M.; Wang, Q.; Zhou B. Chronic exposure to environmental levels of cis-bifenthrin: Enantioselectivity and reproductive effects on zebrafish (Danio rerio). Environmental Pollution, v. 251, p. 175-184, 2019. https://doi.org/10.1016/j.envpol.2019.04.089

License information: This is an open-access article distributed under the terms of the Creative Commons Attribution License, which permits unrestricted use, distribution, and reproduction in any medium, provided the original work is properly cited. 